\title{
Jongeren en hun waarden
}

\author{
Monique van Dijk-Groeneboer a Briene van Herpen-de Regt*
}

\begin{abstract}
Summary
A longitudinal survey was conducted amongst 2300 pupils of secondary confessional schools in the Netherlands. Their religious background, activities and opinions are described and trends therein are searched for. There is a further decline in religious belonging towards traditional religious frameworks. Pupils find inspiration amongst family and friends, in music, sports and nature. Their values are not changing much over time, so still 'being free and independent', 'enjoying life' and 'being happy with oneself' as well as 'being a good human being' and 'adding towards a just society' is valued. When searching for their own words for existential issues their language is found. In the future this language might add to the open dialogues in the classroom. By doing so, a new way has to be found on which religious education and youth ministry can be based.
\end{abstract}

\section{Inleiding}

Sinds 1997 wordt er door de Faculteit Katholieke Theologie van de Universiteit van Tilburg ${ }^{1}$ vijfjaarlijks onderzoek gedaan onder middelbare scholieren. Er wordt een enquête afgenomen onder leerlingen van 4 HAVO en 5 VWO. Daarbij is de centrale vraag: Hoe ziet de religie en zingeving van jongeren eruit? Om deze gegevens in de tijd te vergelijken wordt het grootste deel van de vragen gelijk gehouden. Dit betekent dat een deel van de enquête van 1997 ook in 2017 weer is afgenomen. Dat maakt vergelijking over de tijd mogelijk. Het zijn voornamelijk gesloten vragen. In 2007 hebben we voor het eerst ook een open vraag toegevoegd omdat duidelijk werd dat de oude vragen zich

* Monique van Dijk-Groeneboer is hoogleraar Religieuze Educatie aan de Faculteit Katholieke Theologie van de Universiteit van Tilburg. Zij publiceert nationaal en internationaal over jongeren, hun zingeving en hun religie. $\mathrm{Zij}$ is lid van de Executive Board van de International Association for the Study of Youth Ministry, redactielid van het tijdschrift Handelingen en coördineert de lerarenopleiding voor docenten Godsdienst en Levensbeschouwing.

Briene van Herpen-de Regt deed haar bachelor aan de Fontys Hogeschool voor Theologie en Levensbeschouwing en is masterstudent Theologie aan de Universiteit van Tilburg. Op dit moment werkt zij, als student-assistent van prof. Monique van Dijk-Groeneboer, mee aan het onderzoek Jongeren \& Religie. 
voornamelijk op traditionele, christelijke religie richtten en we merkten dat deze niet meer goed aansloten bij de doelgroep. Daarom wordt sindsdien ook gevraagd welk woord jongeren zelf het liefst gebruiken voor religie, zingeving of levensbeschouwing en wat zij belangrijk vinden op dat gebied. In dit artikel wordt voor het eerst een overzicht gegeven van de kwantitatieve data van 2017 en een eerste indruk van dit laatst beschreven kwalitatieve materiaal. Omdat het om grote aantallen gaat, is de analyse van de antwoorden op de open vraag nog in volle gang en hierover zal later gepubliceerd worden.

Deze enquête is een mooie aanvulling op het onderzoek 'God in Nederland' (Bernts \& Berghuijs 2016) dat de trend van marginalisering van het christendom beschrijft en probeert nieuwe vormen van spiritualiteit en quasireligieuze rituelen toch enigszins in cijfers uit te drukken. Ten tweede bouwt dit onderzoek voort op het Nijmeegse SOCON-project van oorspronkelijk Felling en Schreuder ${ }^{2}$ en inmiddels van Elsinga, Scheepers, Kraaykamp en Thijs (2012), die data hebben verzameld waaruit trends als secularisering en individualisering kunnen worden beschreven en vergeleken. Ten derde en zeker niet ten minste vult dit onderzoek het grote Europese waardenonderzoek (European Values Studies ${ }^{3}$ ) aan, dat mede door Tilburgse collega's van Tilburg School of Social and Behavioral Sciences elke negen jaar wordt uitgevoerd en waarvan elders in deze bundel een bijdrage is aan te treffen. Zij beschrijven hoe in postindustriële, kennisgedreven samenlevingen seculiere, bureaucratische en rationele waarden terrein winnen terwijl in agrarische en industriële samenlevingen religieuze en traditionele waarden belangrijker worden gevonden. De aanvulling van onderhavig onderzoek onder jongeren op de genoemde studies bestaat er vooral uit dat het hier gaat om onderzoek onder middelbare scholieren, en dus om mensen ónder de 18 , die in de andere onderzoeken meestal niet meedoen. Juist de identiteitsvorming en het ontwikkelen van waarden is op deze leeftijd zo belangrijk en derhalve extra interessant voor onderzoek in het kader van religieuze educatie.

Door het gebruik van de originele vragen uit 1997 vragen we naar institutioneel georganiseerde religies op een traditionele manier. Er wordt gevraagd naar religieuze activiteiten, godsbeelden en opvattingen over geloof en kerk. Wel zijn er bij enkele vragen sinds 2012 opties bijgevoegd voor moslimleerlingen, bijvoorbeeld moskeebezoek naast kerkbezoek en lezen in de Koran naast in de Bijbel. Deze gegevens kunnen we in de tijd vergelijken. Tevens zijn sinds 1997 waarden voorgelegd waarvan de leerlingen moeten aangeven of deze voor hen belangrijk zijn of niet. Die waarden geven meer inzicht in wat zij verder in hun leven van waarde vinden, wat hen inspireert. Sinds 2007 vragen we hen dan ook specifiek wie hen inspireert en wat voor hen een inspirerende 
omgeving is. Met de toen ook geïntroduceerde open vraag naar hun eigen woorden voor zingeving, religie of levensbeschouwing krijgen we meer zicht op de taal van jongeren. De centrale vraag in dit onderzoek en derhalve in dit overzichtsartikel is: hoe ziet de religiositeit van jongeren eruit, als we deze traditionele concepten daarvoor gebruiken, en kunnen we in hun waarden en inspiratie taal vinden om tot nieuwe concepten van religiositeit te komen?

\section{Achtergrondgegevens}

Aan de enquête 2017/2018 deden 33 scholen mee, met in totaal 2302 leerlingen uit 4 en 5 havo/vwo. De scholen zijn verzameld via oud-studenten die $\mathrm{nu}$ docent Levensbeschouwing zijn op confessionele scholen, via contacten die zij hebben met collega's van andere scholen, via deelnemers aan studiedagen over Levensbeschouwelijk onderwijs en via een oproep in Narthex, tijdschrift voor docenten Godsdienst/Levensbeschouwing. Dit betekent dat het geen representatieve groep scholen is. Ook zijn er scholen die vijf jaar geleden wel meededen maar nu niet meer, omdat de docent met wie het contact was er niet meer werkt. In 1997 is begonnen met alleen katholieke scholen en sinds 2012 doen ook protestantse scholen mee. Het vak Levensbeschouwing wordt in het openbaar onderwijs niet gegeven waardoor deze scholen niet worden gevraagd mee te doen. Gezien alle ontwikkelingen hierin ${ }^{4}$ is het goed denkbaar dat in 2022 ook daarin verandering wordt gebracht maar voor nu is dat een beperking in het onderzoek. Dit betekent dat er relatief meer leerlingen met een christelijke achtergrond in onze populatie zitten dan landelijk gemiddeld het geval is. Ook zullen er dus minder moslimleerlingen of humanistische leerlingen op deze scholen zitten dan landelijk gemiddeld. Deze kanttekeningen moeten goed in gedachten gehouden worden wanneer in dit artikel - waar dat relevant en mogelijk is - er over de tijd gegevens zullen worden vergeleken. Vergeleken wordt vooral met het peiljaar 2012.

Het onderzoek is uitgevoerd onder jongeren tussen de 14 en de 19, met als gemiddelde leeftijd 16 jaar. De grootste groep leerlingen, 45 procent, was 16 jaar $(n=1.053) .26$ procent van de jongeren was 17 jaar $(n=608) .24$ procent van de scholieren was 15 jaar oud $(n=563)$. De kleine groepen waren die van de leeftijd van 14 ( 2 procent; 41 leerlingen), de leeftijd van 18 (3 procent; 72 leerlingen) en de leeftijd van 19 jaar ( 0,01 procent; 5 leerlingen). De verdeling tussen jongens en meisjes bij dit onderzoek was ongeveer gelijk. Er was 47\% jongen $(n=1096)$ en $53 \%$ van de respondenten was meisje $(n=1253)$. 
De 33 scholen die meededen zijn van verschillende confessionele achtergronden. We hebben hierbij gekeken naar wat in hun visie en soms ook op hun gevel staat. Soms is dit 'protestants-christelijk', soms specifieker, bijvoorbeeld 'reformatorisch'. In grafiek 1 is de verdeling qua aantallen deelnemende leerlingen in het onderzoek zichtbaar.

\section{Grafiek 1 Verdeling van scholen naar denominatie}

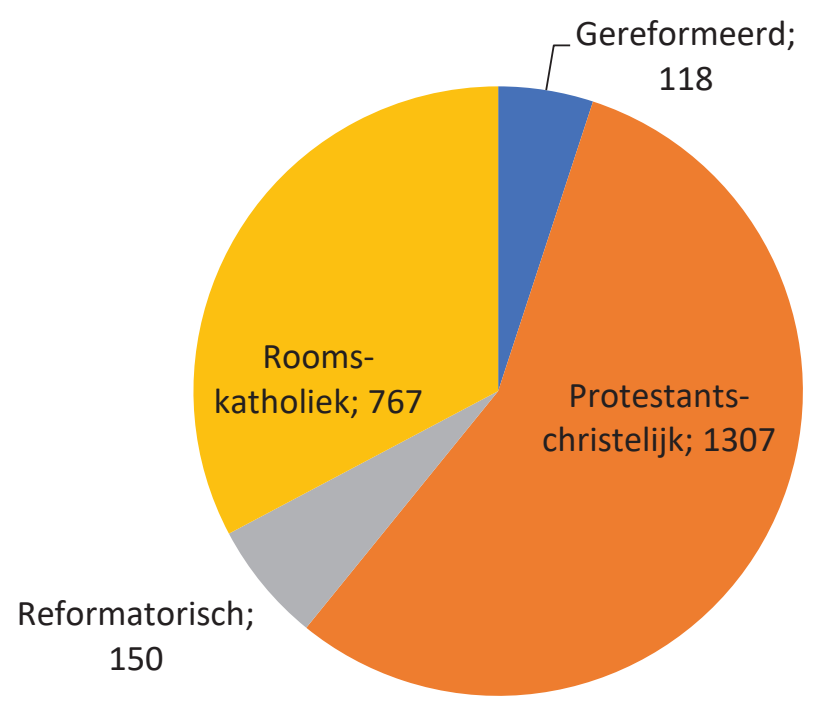

Het grootste gedeelte leerlingen is afkomstig van een 'protestants-christelijke' school. Het gaat hierbij om 1307 leerlingen van 17 scholen. Er waren 12 'rooms-katholieke' scholen met samen 767 leerlingen. Een 'reformatorische' school deed mee met 150 scholieren en er waren 2 'gereformeerde' scholen met 118 leerlingen. In 2012 deden vooral veel katholieke scholen mee wat de populatie anders maakt dan in 2017 en bij de vergelijking over de tijd in acht moet worden genomen.

\section{Religiositeit van leerlingen}

Iedere vijf jaar proberen we inzicht te krijgen in de religiositeit van leerlingen. We zoeken daarnaar op een traditionele en ondertussen verouderde manier, omdat we vanuit een katholiek praktisch-theologisch perspectief zijn vertrokken in 1997. Daarin zitten op traditionele, christelijke religie gestoelde denkbeelden die tot uiting komen in vragen zoals het naar de kerk gaan, bidden, 
bijbellezen en bepaalde godsbeelden. Al in de loop van de onderzoeken blijkt, zoals ook uit ander onderzoek naar voren komt, dat deze elementen van kerkelijke religie voor jongeren, evenals voor jongvolwassenen ondertussen, minder relevant aan het worden zijn. Toch houden we, zoals gezegd, deze opzet van de enquête in stand om de gegevens over de jaren te kunnen blijven vergelijken. Daarom presenteren we hier opnieuw hun eigen keuze van hun levensbeschouwing, de identiteit van de school, religieuze activiteiten, bidden en godsbeelden. In de laatste paragraaf van dit hoofdstuk koppelen we deze data aan de eerder ontwikkelde typologie van de religiositeit van jongeren (Van Dijk-Groeneboer 2010).

\subsection{Levensbeschouwing van leerlingen}

We hebben de leerlingen gevraagd aan te geven hoe ze zichzelf noemen qua levensbeschouwing. Dit geeft de volgende verdeling te zien.

\section{Grafiek 2 Religieuze zelfbeschrijving van leerlingen}

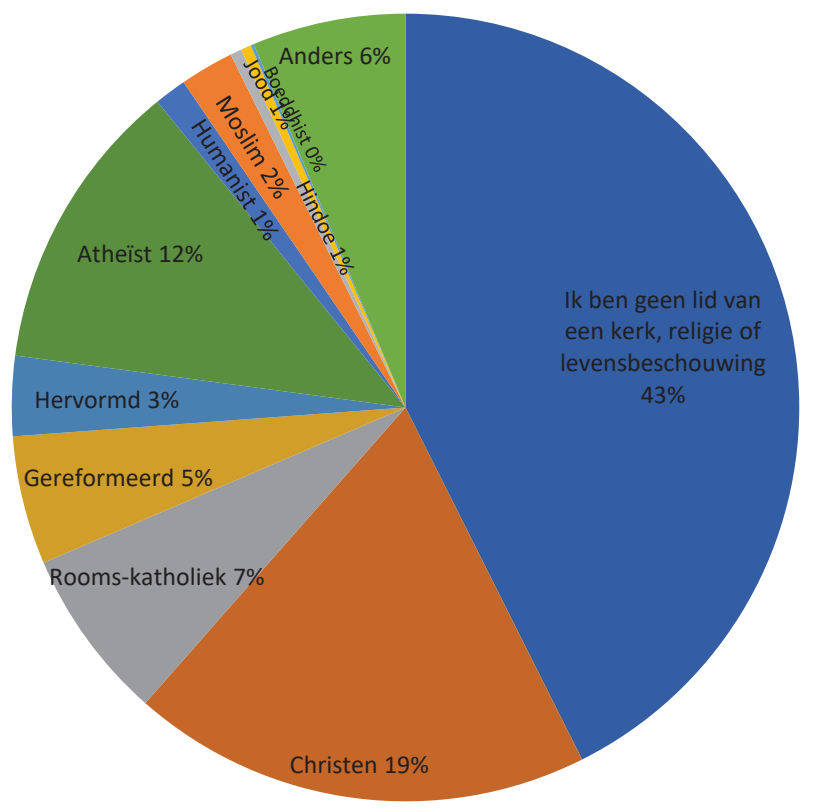

Het grootste deel van de leerlingen geeft aan 'geen lid van kerk of religie of levensbeschouwing' te zijn (43 procent). 19 procent noemt zich christen, 3 procent hervormd, 5 procent gereformeerd en 7 procent rooms-katholiek. Doordat niet duidelijk is wat ze bedoelen als ze aankruisen 'christen', is het niet helder of ze geschaard kunnen worden bij een van de andere drie opties 
van christelijke religies. In totaal noemt 34 procent van de leerlingen dus een christelijke religie. 12 procent noemt zich atheïst, 2 procent moslim, 1 procent humanist, 1 procent jood en 1 procent hindoe. Bij 'anders' ( 6 procent totaal) noemden 22 leerlingen zichzelf pastafari. 19 leerlingen gaven een andere vorm aan van protestantisme. 18 Leerlingen zeiden niet gelovig te zijn, en hadden dus ook voor 'geen lid...' kunnen kiezen. 17 leerlingen noemden zich agnost. 13 leerlingen gaven een ietsistische beschrijving, zoals: 'Beetje humanist, maar ik geloof wel dat er 'iets' is dat ons begrip te boven gaat.'

In 2012 deden zoals gezegd meer katholieke scholen mee en was ook de religieuze zelfbeschrijving van de leerlingen anders dan in de huidige populatie. In 2012 noemde 16 procent van de respondenten zichzelf roomskatholiek, 3 procent hervormd, 3 procent gereformeerd, 14 procent christelijk, 3 procent moslim, 14 procent atheïst, 2 procent humanist en 38 procent gaf aan geen lid te zijn van een kerk, religie of levensbeschouwing.

In 2007 deden alleen katholieke scholen mee aan het onderzoek, en toen noemde 40 procent van de leerlingen zich katholiek en 4 procent christelijk. 43 procent zei toen 'geen lid van kerk of religie' te zijn maar de optie 'atheïst' was in 2007 nog niet toegevoegd wat doet vermoeden dat deze groep zich bij die 43 procent schaarde.

Wanneer de achtergrond van de scholen niet in ogenschouw wordt genomen, zou geconcludeerd kunnen worden dat het aantal katholieke leerlingen afneemt en het aantal dat geen lid is van een religie of levensbeschouwing of atheïst is toeneemt. Nadere bestudering hiervan is zinvol, maar daarvoor is eerst meer informatie nodig over de identiteit van de scholen die in dit onderzoek hebben meegedaan.

\subsection{Identiteit van de school}

Wanneer we de formele identiteit van de school verdelen in protestantschristelijk, gereformeerd, reformatorisch en katholiek, kunnen we kijken hoe leerlingen bijvoorbeeld zichzelf noemen en hoe zich dit verhoudt tot die identiteit van de school. 
Tabel 1 Zelfbeschrijving van leerlingen verdeeld naar denominaties van scholen

\begin{tabular}{lcccc}
\hline School/leerling & $\begin{array}{c}\text { Protestants- } \\
\text { christelijk }\end{array}$ & Reformatorisch & Gereformeerd & Rooms-katholiek \\
\hline Rooms-katholiek & 3,5 & 0 & 0 & 15,5 \\
Hervormd & 1,8 & 22,7 & 7,6 & 1,4 \\
Gereformeerd & 2,1 & 36,7 & 31,4 & 0,5 \\
Christen & 20,4 & 34,7 & 47,5 & 9 \\
Moslim & 1,9 & 0,7 & 0 & 3,4 \\
Jood & 0,2 & 0 & 0 & 0,9 \\
Boeddhist & 0 & 1,3 & 0 & 0 \\
Hindoe & 0,5 & 0 & 0 & 0,5 \\
Atheïst & 11,7 & 2 & 3,4 & 15,9 \\
Humanist & 1,2 & 0 & 0,8 & 1,8 \\
Geen lid & 50,3 & 1,3 & 0,8 & 43,9 \\
Anders & 6,4 & 0,6 & 8,5 & 7,2 \\
\hline Totaal & $100 \%(\mathrm{~N}=1307)$ & $100 \%(\mathrm{~N}=150)$ & $100 \%(\mathrm{~N}=118)$ & $100 \%(\mathrm{~N}=767)$ \\
\hline
\end{tabular}

Uit tabel 1 blijkt dat op protestants-christelijke scholen en katholieke scholen veel leerlingen (respectievelijk de helft en bijna de helft) aankruisen 'geen lid te zijn van een religie of levensbeschouwing'. Ook geeft ruim een tiende deel van de populatie op deze scholen aan atheïst te zijn. Op reformatorische en gereformeerde scholen is meer dan 90 procent hervormd, gereformeerd of christen. Het gaat om een gering aantal scholen dus we kunnen dit cijfer niet generaliseren voor alle schooltypen in Nederland, maar het geeft wel een indicatie.

We hebben ook gevraagd waarom voor deze confessionele school gekozen is. Er konden meerdere antwoorden worden aangekruist. In het totaal werd vooral voor de school gekozen vanwege de sfeer op school (41,2 procent), de afstand (36,6 procent), dat de school goed bekend staat (31,1 procent), of omdat er vrienden op zaten (25,5 procent). Het antwoord 'vanwege de (religieuze) identiteit van de school' werd - mede, naast andere antwoorden - aangekruist door 52,5 procent van de leerlingen op gereformeerde scholen, 68,7 procent van de leerlingen op reformatorische scholen, 5,4 procent van de leerlingen op protestants-christelijke scholen en 0,9 procent van de leerlingen op katholieke 
scholen. Voor deze laatste twee speelt identiteit van de school dus nauwelijks een rol. Deze cijfers verschillen nauwelijks van die uit 2012, waar ook de afstand, de bekendheid en de sfeer van de school het meest belangrijk waren.

Wanneer we 'hoe je jezelf omschrijft qua levensbeschouwing' als uitgangspunt nemen, zijn er ook interessante dwarsverbanden te leggen. Wanneer we dan kijken welke leerlingen de school hebben gekozen mede vanwege de identiteit van de school, dan geldt dit voor 3 procent van de katholieke leerlingen, 40,3 procent van de hervormde leerlingen, 60,2 procent van de gereformeerde leerlingen, 26,2 procent van de christelijke leerlingen, 0,4 procent van de atheïstische leerlingen, 9,7 procent van de humanistische leerlingen en 0,5 procent van de leerlingen die zich geen lid van religie of levensbeschouwing noemen. Voor de moslimleerlingen speelde de identiteit van de school geen rol bij de schoolkeuze.

\subsection{Geloof, religie en instituut}

Het blijft zoeken hoe de begrippen geloof, religie en kerk- en moskeegang met elkaar verband houden bij jongeren van nu, die opgroeien in een tijd waar deze woorden uit het taalveld verdwenen zijn en ook de gewoonte van kerk- en moskeegang sterk is afgenomen. Daartoe hebben we hen vier stellingen voorgelegd waarop zij konden aangeven met welke stelling zij het meest instemden. De vier stellingen vertegenwoordigen vier posities omtrent de samenhang van gelovig zijn, een religie nodig hebben en het bijwonen van diensten. De antwoorden hebben we ook uitgesplitst naar religieuze achtergrond, en in procenten weergegeven. Dus van de 149 (=100 procent) katholieke leerlingen koos 8 procent voor de eerste stelling, van de 114 gereformeerde leerlingen koos 45 procent voor deze stelling, enzovoorts. 
Tabel 2 Percentages leerlingen die stelling bevestigen, per religieuze zelfbeschrijving, allen èn in vergelijking met 2012

\begin{tabular}{|c|c|c|c|c|c|}
\hline $\begin{array}{l}\text { Levens- } \\
\text { beschouwing } \\
\text { Stelling }\end{array}$ & $\begin{array}{l}\text { Als je gelovig } \\
\text { bent moet je } \\
\text { lid zijn van } \\
\text { een religie } \\
\text { en met } \\
\text { regelmaat } \\
\text { diensten (in } \\
\text { kerk, moskee } \\
\text { of tempel) } \\
\text { bijwonen }\end{array}$ & $\begin{array}{l}\text { Als je gelovig } \\
\text { bent hoef } \\
\text { je niet lid te } \\
\text { zijn van een } \\
\text { religie, maar } \\
\text { je moet wel } \\
\text { met zekere } \\
\text { regelmaat } \\
\text { diensten } \\
\text { bijwonen }\end{array}$ & $\begin{array}{l}\text { Als je gelovig } \\
\text { bent heb je } \\
\text { geen religie } \\
\text { nodig en hoef } \\
\text { je ook niet } \\
\text { diensten bij } \\
\text { te wonen. }\end{array}$ & $\begin{array}{l}\text { Als je gelovig } \\
\text { bent hoor } \\
\text { je bij een } \\
\text { bepaalde } \\
\text { religie/ } \\
\text { bepaald } \\
\text { geloof, maar } \\
\text { je hoeft } \\
\text { niet per se } \\
\text { diensten bij } \\
\text { te wonen. Je } \\
\text { kunt echter } \\
\text { niet zonder } \\
\text { officiële } \\
\text { religie }\end{array}$ & \\
\hline Rooms-katholiek & 8 & 9 & 49 & 34 & $100(\mathrm{~N}=149)$ \\
\hline Hervormd & 37 & 22 & 14 & 27 & $100(\mathrm{~N}=73)$ \\
\hline Gereformeerd & 45 & 21 & 10 & 25 & $100(N=114)$ \\
\hline Christen & 18 & 12 & 33 & 37 & $100(\mathrm{~N}=394)$ \\
\hline Moslim & 39 & 12 & 17 & 32 & $100(\mathrm{~N}=41)$ \\
\hline Atheïst & 6 & 7 & 52 & 35 & $100(\mathrm{~N}=265)$ \\
\hline Humanist & 0 & 11 & 61 & 29 & $100(N=28)$ \\
\hline Geen & 6 & 10 & 48 & 34 & $100(\mathrm{~N}=904)$ \\
\hline Alle leerlingen & 13 & 11 & 42 & 34 & $100(\mathrm{~N}=1968)$ \\
\hline Data 2012 & 9 & 12 & 46 & 33 & $100(N=1400)$ \\
\hline
\end{tabular}

In totaal vindt 42 procent van alle respondenten dat je geen religie nodig hebt en geen diensten hoeft bij te wonen als je gelovig bent. Het bijwonen van diensten wordt vooral door gereformeerde, hervormde en moslimleerlingen gekoppeld aan gelovig zijn. Dit uit zich vooral ook in een lidmaatschap (gemiddeld 40 procent) of in elk geval in het bezoek van diensten (nog eens 21,5 procent van de protestantse en 12 procent van de moslimleerlingen). Het lid zijn van een religie wordt vooral door gereformeerde, hervormde en moslimleerlingen gekoppeld aan gelovig zijn. Het bijwonen van diensten is voor gemiddeld een derde van alle leerlingen niet essentieel om gelovig te zijn, maar tegelijk is wel het hebben van een officiële religie nodig. In deze vraag is nauwelijks verschil te zien met de cijfers uit 2012 . 


\subsection{Religieuze activiteiten}

We hebben de leerlingen naar andere opvattingen aangaande religie en naar hun religieuze activiteiten gevraagd. We hebben de percentages op de antwoorden 'mee eens' en 'helemaal mee eens' bij elkaar opgeteld en vervolgens uitgesplitst naar de zelfbeschrijving van hun levensbeschouwing.

Tabel 3 Percentages leerlingen die op de stelling 'mee eens' of 'helemaal mee eens' antwoorden, uitgesplitst naar religieuze zelfbeschrijving

\begin{tabular}{lcccccccc}
\hline & $\begin{array}{l}\mathrm{RK} \\
(\mathrm{N}=153)\end{array}$ & $\begin{array}{l}\text { Her- } \\
\text { vormd } \\
(\mathrm{N}=75)\end{array}$ & $\begin{array}{l}\text { Gerefor- } \\
\text { meerd } \\
(\mathrm{N}=119)\end{array}$ & $\begin{array}{l}\text { Christen } \\
(\mathrm{N}=417)\end{array}$ & $\begin{array}{c}\text { Moslim } \\
(\mathrm{N}=45)\end{array}$ & $\begin{array}{l}\text { Atheïst } \\
(\mathrm{N}=271)\end{array}$ & $\begin{array}{l}\text { Huma- } \\
\text { nist } \\
(\mathrm{N}=30)\end{array}$ & $\begin{array}{l}\text { Geen } \\
(\mathrm{N}=959)\end{array}$ \\
\hline $\begin{array}{l}\text { Ik ben religieus } \\
\text { of gelovig }\end{array}$ & 65 & 90 & 90 & 78 & 93 & 3 & 11 & 7 \\
$\begin{array}{l}\text { Ik weet precies } \\
\text { waarin ik geloof } \\
\text { Ik wil wel }\end{array}$ & 48 & 63 & 67 & 57 & 90 & 48 & 54 & 36 \\
$\begin{array}{l}\text { geloven maar } \\
\text { kan het niet }\end{array}$ & 25 & 34 & 31 & 25 & 5 & 12 & 46 & 10 \\
$\begin{array}{l}\text { Ik vind 'geloof' } \\
\text { ouderwets en } \\
\text { achterhaald }\end{array}$ & 34 & 4 & 4 & 15 & 5 & 58 & 39 & 40 \\
$\begin{array}{l}\text { Als ik later } \\
\text { trouw wil ik dat } \\
\text { in kerk/moskee }\end{array}$ & 45 & 75 & 79 & 59 & 64 & 5 & 7 & 10 \\
$\begin{array}{l}\text { Als ik kinderen } \\
\text { krijg ga ik }\end{array}$ & 25 & 73 & 77 & 58 & 85 & 0 & 0 & 3 \\
hen religieus \\
$\begin{array}{l}\text { opvoeden } \\
\text { Ik wil een } \\
\text { religieuze } \\
\text { begrafenis }\end{array}$
\end{tabular}

Uit tabel 3 wordt duidelijk dat de hervormde, gereformeerde en moslimjongeren zich bijna altijd religieus noemen. Voor viervijfde van de christelijke en tweederde van de katholieke leerlingen is dit ook het geval. Atheïsten, humanisten, leerlingen zonder lidmaatschap van religie of levensbeschouwing en katholieke leerlingen geven regelmatig aan dat ze geloof ouderwets of achterhaald vinden (een derde tot de helft van hen). Trouwen, begraven worden of opvoeden van kinderen wordt door een meerderheid van de 
protestantse en islamitische leerlingen aan religie gekoppeld, en door de helft van de katholieke leerlingen eveneens.

Ook een aantal religieuze evenementen hebben we de leerlingen voorgelegd met de vraag of ze de intentie hebben eraan deel te nemen, en we hebben gevraagd of ze thuis een heilig boek hebben. Hieronder wordt het percentage weergegeven dat 'ja' antwoordde op de geformuleerde vraag.

Tabel 4 Percentages leerlingen die op de vraag 'mee eens' of 'helemaal mee eens' antwoorden, uitgesplitst naar religieuze zelfbeschrijving

\begin{tabular}{|c|c|c|c|c|c|c|c|c|}
\hline & $\begin{array}{l}\text { RK } \\
(N=145)\end{array}$ & $\begin{array}{l}\text { Her- } \\
\text { vormd } \\
(\mathrm{N}=71)\end{array}$ & $\begin{array}{l}\text { Gerefor- } \\
\text { meerd } \\
(\mathrm{N}=108)\end{array}$ & $\begin{array}{l}\text { Christen } \\
(N=371)\end{array}$ & $\begin{array}{l}\text { Moslim } \\
(\mathrm{N}=39)\end{array}$ & $\begin{array}{l}\text { Atheïst } \\
(\mathrm{N}=260)\end{array}$ & $\begin{array}{l}\text { Huma- } \\
\text { nist } \\
(\mathrm{N}=28)\end{array}$ & $\begin{array}{l}\text { Geen } \\
(\mathrm{N}=875)\end{array}$ \\
\hline $\begin{array}{l}\text { Hebben jullie thuis } \\
\text { een heilig boek } \\
\text { (Koran, Bijbel, } \\
\text { Tenach bv) }\end{array}$ & 45 & 96 & 97 & 85 & 95 & 36 & 32 & 34 \\
\hline $\begin{array}{l}\text { Zou je willen } \\
\text { deelnemen aan een } \\
\text { stille tocht? }\end{array}$ & 10 & 10 & 9 & 9 & 5 & 5 & 4 & 4 \\
\hline $\begin{array}{l}\text { Zou je willen } \\
\text { deelnemen aan de } \\
\text { katholieke Wereld- } \\
\text { jongerendagen? }\end{array}$ & 3 & 0 & 2 & 1 & 0 & 0 & 7 & 1 \\
\hline $\begin{array}{l}\text { Zou je ooit op } \\
\text { bedevaart naar } \\
\text { Mekka willen gaan } \\
\text { (Hadj)? }\end{array}$ & 0 & 0 & 0 & 2 & 77 & 1 & 4 & 1 \\
\hline $\begin{array}{l}\text { Zou je met de } \\
\text { Ramadan willen } \\
\text { meedoen? }\end{array}$ & 8 & 3 & 2 & 3 & 87 & 3 & 18 & 5 \\
\hline $\begin{array}{l}\text { Zou je de EO- } \\
\text { jongerendag willen } \\
\text { meemaken? }\end{array}$ & 4 & 27 & 22 & 25 & 0 & 1 & 21 & 2 \\
\hline $\begin{array}{l}\text { Zou je Chanoeka } \\
\text { willen vieren? }\end{array}$ & 1 & 4 & 1 & 1 & 0 & 2 & 11 & 2 \\
\hline $\begin{array}{l}\text { Zou je naar Taizé } \\
\text { willen gaan? }\end{array}$ & 5 & 3 & 2 & 4 & 0 & 2 & 18 & 2 \\
\hline
\end{tabular}

Een heilig boek is in veel huizen aanwezig. De overige activiteiten krijgen niet veel bijval met als uitzondering de Ramadan en de Hadj voor moslimleerlingen.

Vervolgens is gevraagd hoe vaak jongeren de volgende activiteiten doen. In de tabel staan de gewogen gemiddelden op een vijfpuntschaal van nee/nooit tot heel vaak. 
Tabel 5 Gewogen gemiddelden van de antwoorden op een vijfpuntschaal van nee/nooit tot heel vaak, uitgesplitst naar religieuze zelfbeschrijving

\begin{tabular}{|c|c|c|c|c|c|c|c|c|}
\hline & $\begin{array}{l}\text { RK } \\
(\mathrm{N}=153)\end{array}$ & $\begin{array}{l}\text { Her- } \\
\text { vormd } \\
(\mathrm{N}=75)\end{array}$ & $\begin{array}{l}\text { Gerefor- } \\
\text { meerd } \\
(\mathrm{N}=119)\end{array}$ & $\begin{array}{l}\text { Christen } \\
(\mathrm{N}=417)\end{array}$ & $\begin{array}{l}\text { Moslim } \\
(\mathrm{N}=45)\end{array}$ & $\begin{array}{l}\text { Atheïst } \\
(\mathrm{N}=271)\end{array}$ & $\begin{array}{l}\text { Huma- } \\
\text { nist } \\
(\mathrm{N}=30)\end{array}$ & $\begin{array}{l}\text { Geen } \\
(\mathrm{N}=959)\end{array}$ \\
\hline $\begin{array}{l}\text { Lees je in een } \\
\text { Heilig Boek, } \\
\text { zoals Koran of } \\
\text { Bijbel? }\end{array}$ & 1.46 & 3.49 & 3.72 & 2.69 & 2.82 & 1.15 & 1.43 & 1.17 \\
\hline $\begin{array}{l}\text { Ga je vaak naar } \\
\text { diensten in } \\
\text { moskee, kerk, } \\
\text { synagoge? }\end{array}$ & 2.15 & 4 & 4.07 & 3.15 & 2.62 & 1.24 & 1.61 & 1.25 \\
\hline $\begin{array}{l}\text { Praat je met } \\
\text { je ouders } \\
\text { over religie of } \\
\text { godsdienst? }\end{array}$ & $2.1 \mathrm{~W}$ & 3.17 & 3.28 & 2.9 & 3.72 & 2.07 & 2.21 & 1.78 \\
\hline $\begin{array}{l}\text { Ga je met } \\
\text { belangrijke } \\
\text { feestdagen } \\
\text { naar vieringen/ } \\
\text { diensten? }\end{array}$ & 2.66 & 4.27 & 4.31 & 3.5 & 3.33 & 1.39 & 1.82 & 1.4 \\
\hline $\begin{array}{l}\text { Gaan je ouders } \\
\text { naar diensten/ } \\
\text { vieringen? }\end{array}$ & 2.28 & 4.1 & 4.31 & 3.43 & 3.44 & 1.46 & 1.89 & 1.33 \\
\hline $\begin{array}{l}\text { Verplichtten } \\
\text { je ouders jou } \\
\text { vroeger mee } \\
\text { te gaan naar } \\
\text { diensten/ } \\
\text { vieringen? }\end{array}$ & 2.39 & 3.93 & 3.88 & 3.38 & 2 & 1.52 & 1.71 & 1.41 \\
\hline $\begin{array}{l}\text { Ben je gelovig } \\
\text { opgevoed? }\end{array}$ & 2.93 & 4.52 & 4.52 & 4.07 & 4.44 & 1.65 & 1.89 & 1.57 \\
\hline
\end{tabular}

Er wordt door hervormde, gereformeerde en in iets mindere mate door christelijke en moslimleerlingen gelezen in de Bijbel of Koran. De betrokkenheid bij een religieus instituut, dat zich uit in bezoek van diensten of vieringen, is vooral zichtbaar bij hervormde en gereformeerde leerlingen en in iets mindere mate ook bij christelijke en moslimleerlingen. Katholieke leerlingen gaan daar opvallend minder vaak naartoe, ook bij feestdagen. De ouders gaan volgens de leerlingen nagenoeg vergelijkbaar vaak of weinig. Verplichten naar diensten te gaan gebeurde vroeger bij hervormde en gereformeerde leerlingen en in mindere mate bij christelijke leerlingen. De hervormde, gereformeerde, christelijke en islamitische leerlingen vinden zichzelf gelovig opgevoed, de 
anderen niet of nauwelijks. Naast deze cijfers is ook door 2,2 procent van alle leerlingen twee keer of vaker meegedaan aan een stille tocht en 7 procent zou dat wel willen. Door 4,6 procent is twee of meer keer meegedaan aan de EO-jongerendag $(11,2 \%$ van de hervormde leerlingen, $9,2 \%$ van de gereformeerde leerlingen, $14,5 \%$ van de christelijke jongeren, 10,7\% van de humanistische jongeren en $0,9 \%$ van de leerlingen die geen lid van een religie of levensbeschouwing zijn) en 9 procent zou dat wel willen. Van alle moslimleerlingen heeft 84,6 procent twee keer of vaker meegedaan aan de Ramadan en 7,1 procent van de humanistische leerlingen ook. 87 procent van de moslimleerlingen heeft de intentie mee te doen aan de Ramadan en 77 procent om mee te doen aan de Hadj.

\subsection{Bidden}

In ieder onderzoek vragen we of jongeren bidden, en zo ja hoe vaak en wanneer dan. Dit werd gescoord op een vijfpuntschaal.

\section{Grafiek 3 Percentages van bidden}

\section{Bid je? Hoe vaak en wanneer?}

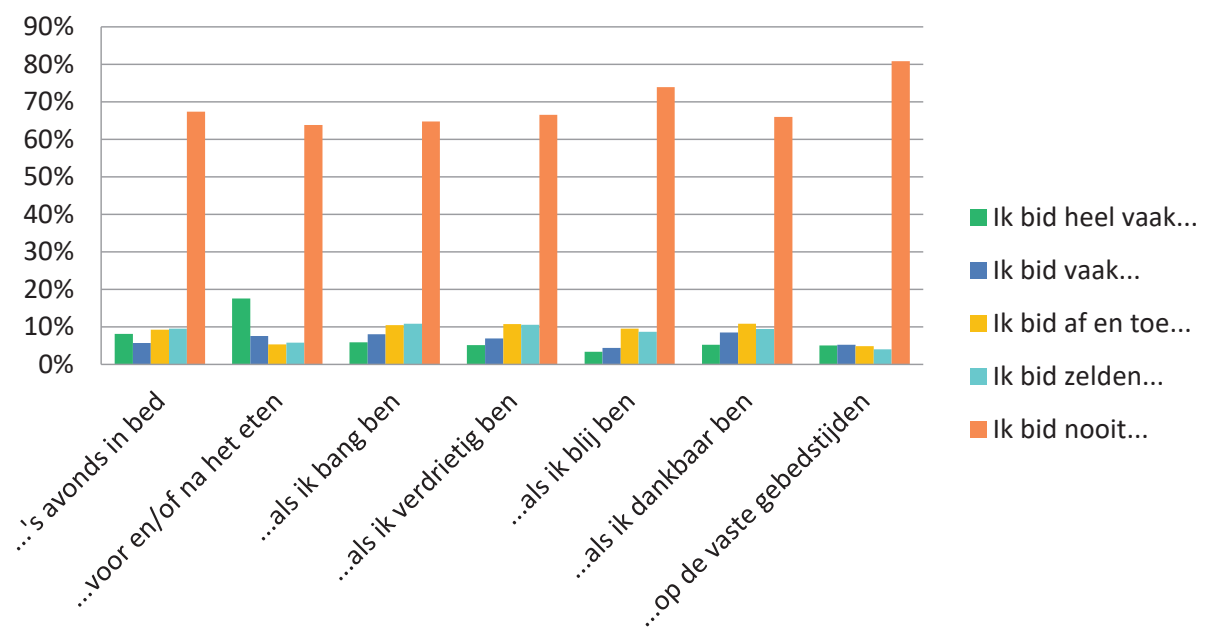

Deze gegevens hebben we ook uitgesplitst naar religieuze zelfbeschrijving van leerlingen, wat een volgend overzicht geeft. Hierbij zijn de percentages 'vaak' en 'heel vaak' bij elkaar opgeteld. 
Tabel 6 Vaak of heel vaak bidden op diverse momenten, uitgesplitst naar religieuze zelfbeschrijving, allen ( $\mathrm{N}=1897)$ èn in vergelijking met 2012 ( $\mathrm{N}=1400)$

\begin{tabular}{|c|c|c|c|c|c|c|c|}
\hline & 's Avonds & $\begin{array}{l}\text { Rond } \\
\text { maaltijd }\end{array}$ & Bang & Verdrietig & Blij & Dankbaar & Vaste tijden \\
\hline $\begin{array}{l}\text { Rooms-katholiek } \\
(n=145)\end{array}$ & 9 & 9 & 10 & 9 & 5 & 11 & 3 \\
\hline Hervormd $(n=71)$ & 49 & 84 & 46 & 42 & 21 & 49 & 37 \\
\hline $\begin{array}{l}\text { Gereformeerd } \\
(n=108)\end{array}$ & 51 & 89 & 49 & 36 & 21 & 42 & 38 \\
\hline Christen $(n=371)$ & 30 & 63 & 31 & 28 & 16 & 29 & 21 \\
\hline Moslim ( $n=39)$ & 49 & 31 & 52 & 44 & 36 & 62 & 46 \\
\hline Atheïst $(n=260)$ & 3 & 5 & 3 & 3 & 3 & 2 & 3 \\
\hline Humanist ( $n=28$ ) & 0 & 7 & 0 & 0 & 0 & 0 & 0 \\
\hline Geen $(n=875)$ & 2 & 5 & 3 & 2 & 2 & 3 & 1 \\
\hline Alle leerlingen & 13,7 & 25,1 & 13,8 & 12 & 7,3 & 12,5 & 9,9 \\
\hline Data 2012 & 10 & 18 & 9 & 9 & 6 & 12 & 7 \\
\hline
\end{tabular}

In totaal bidt 13,7 procent van de leerlingen vaak of heel vaak 's avonds in bed en 77,1 procent zelden of nooit. Ongeveer de helft van de hervormde, de gereformeerde en de moslimleerlingen bidt vaak of heel vaak 's avonds in bed, maar de katholieke, atheïstische, humanistische leerlingen en leerlingen die niet lid zijn van een religie of levensbeschouwing bidden zelden of nooit.

25,1 procent bidt vaak of heel vaak voor en/of na het eten en 69,7 procent zelden of nooit. Vooral hervormde, gereformeerde en christelijke leerlingen bidden vaak of regelmatig rond de maaltijden en een derde van de moslimleerlingen.

13,8 procent van de leerlingen bidt vaak of heel vaak als ze bang zijn en 75,3 procent zelden of nooit. Dit geldt voor de helft van de gereformeerde en islamitische leerlingen en voor twee-vijfde van de hervormde leerlingen. 12 procent bidt vaak of heel vaak als ze verdrietig zijn en 77 procent zelden of nooit. 7,3 procent van de leerlingen bidt als ze blij zijn en 83 procent zelden of nooit. Dit geldt voor 36 procent van de moslimleerlingen en voor 20 procent van de hervormde en de gereformeerde leerlingen. 12,5 procent van de leerlingen bidt vaak of heel vaak als ze dankbaar zijn terwijl 75,6 dat zelden of nooit doet. Dit geldt voor 62 procent van de moslimleerlingen, 49 procent van de hervormde en 42 procent van de gereformeerde leerlingen.

Op vaste gebedstijden wordt gebeden door 9,9 procent van de leerlingen terwijl 85 procent dat zelden of nooit doet. 46 procent van de moslimleerlingen bidt vaak of heel vaak op vaste gebedstijden evenals 38 procent van 
de gereformeerde en 36 procent van de hervormde leerlingen. Ten opzichte van 2012 laten deze cijfers zien dat het bidden niet minder is geworden. Voorzichtigheid is geboden vanwege de andere religieuze achtergrond van de leerlingen in de twee cohorten.

\subsection{Godsbeelden}

Iedere vijf jaar wordt de leerlingen een reeks stellingen over godsbeelden voorgelegd met de vraag in hoeverre zij het daarmee eens zijn. In tabel 7 is het overzicht te zien van de antwoorden.

\section{Tabel 7 Godsbeelden. Percentages respondenten die respectievelijk 'zeer mee eens' of 'mee eens' (samengevoegd tot 'eens') scoorden en 'zeer mee oneens' of 'mee oneens' (samengevoegd tot 'oneens')}

\begin{tabular}{lll}
\hline $\begin{array}{l}\text { Stelling } \backslash \text { percentage eens of helemaal mee eens } \text { \percentage mee } \\
\text { oneens of helemaal mee oneens }\end{array}$ & eens & oneens \\
\hline God is voor mij het waardevolle in de mens & 14,2 & 60,3 \\
Er is een God die zich met ieder mens persoonlijk bezighoudt & 23,1 & 53,5 \\
Er bestaat iets hogers dat we niet in woorden kunnen vatten & $36,2 *$ & 37,9 \\
God is dichtbij, in de harten van de mensen & 26 & 48,3 \\
leder mens heeft in zijn diepste zelf een goddelijke vonk & 13,1 & 55,5 \\
Er bestaat een hogere macht & $32,9 *$ & 38 \\
Ik beschouw God als een man met een baard die op een wolk zit & 16 & $65,3 *$ \\
leder mens is zelf een onderdeeltje van God & 13,4 & 60,6 \\
God straft als iemand iets verkeerd doet & 11,6 & 62,2 \\
God is gewoon een ander woord voor de natuur & 9,7 & $65 *$ \\
God is degene die jouw levenspad bepaalt & 17,5 & 63,7 \\
De mensen hebben God uitgevonden om hun verantwoordelijkheid & 20,9 & 63,8 \\
daarop af te kunnen schuiven & 30,5 & 42 \\
Er bestaat 'iets hogers' dat in alle godsdiensten weer anders wordt & & \\
genoemd & 19,5 & 56,3 \\
Er bestaat een God wiens rijk komende is & 19,8 & 59,3 \\
God is degene die van tevoren ziet wat in jouw leven gebeurt & 28,7 & 48 \\
God is overal en altijd & 24,6 & 44,5 \\
God is de schepper van al wat is & 20,5 & 56,6 \\
God is de rechter der rechters & $32,4 *$ & 38,1 \\
God is goed en rechtvaardig & 29,5 & 47,8 \\
God is groter dan mensen ooit kunnen bevatten & 12,5 & $66,7 *$ \\
God roept mij & & \\
\hline & & \\
\hline
\end{tabular}


De top drie van stellingen die het meest is gescoord als 'mee eens' of 'helemaal mee eens' is:

Er bestaat iets hogers dat we niet in $36,2 \%$ woorden kunnen vatten

Er bestaat een hogere macht $32,9 \%$

God is goed en rechtvaardig $32,4 \%$

Het hogere van God wordt door de leerlingen dus vaak instemmend beoordeeld, dit kan ook passen bij ietsisten bijvoorbeeld, die wel van mening zijn dat er 'iets' is. Ook het goede en rechtvaardige van God wordt door een derde van de leerlingen erkend. In 2012 was de top drie vergelijkbaar:

Er is iets hogers dat we niet in woorden $33 \%$ kunnen vatten

Er bestaat 'iets hogers' dat in alle gods$29 \%$ diensten weer anders wordt genoemd Er bestaat een hogere macht $29 \%$

Het antwoord 'God is goed en rechtvaardig' kwam toen op de vijfde plek met 26 procent.

De verdeling over denominaties en levensbeschouwingen, uitgedrukt in de religieuze zelfbeschrijving van leerlingen, bij de scores op deze stellingen is als volgt (in percentages die scoorden 'mee eens' of 'helemaal mee eens').

Tabel 8 Drie meest vaak als belangrijk gescoorde godsbeelden, uitgesplitst naar religieuze zelfbeschrijving

\begin{tabular}{lcccccccc}
\hline & $\begin{array}{l}\text { RK } \\
(\mathrm{N}=140)\end{array}$ & $\begin{array}{l}\text { Her- } \\
\text { vormd } \\
(\mathrm{N}=68)\end{array}$ & $\begin{array}{l}\text { Gerefor- } \\
\text { meerd } \\
(\mathrm{N}=107)\end{array}$ & $\begin{array}{l}\text { Christen } \\
(\mathrm{N}=359)\end{array}$ & $\begin{array}{l}\text { Moslim } \\
(\mathrm{N}=38)\end{array}$ & $\begin{array}{l}\text { Atheïst } \\
(\mathrm{N}=249)\end{array}$ & $\begin{array}{l}\text { Huma- } \\
\text { nist } \\
(\mathrm{N}=27)\end{array}$ & $\begin{array}{l}\text { Geen } \\
(\mathrm{N}=851)\end{array}$ \\
\hline $\begin{array}{l}\text { Er bestaat iets } \\
\text { hogers dat we } \\
\text { niet in woorden } \\
\text { kunnen vatten }\end{array}$ & 43 & 72 & 68 & 60 & 68 & 16 & 33 & 22 \\
$\begin{array}{l}\text { Er bestaat } \\
\text { een hogere }\end{array}$ & 37 & 79 & 78 & 61 & 58 & 12 & 26 & 16 \\
$\begin{array}{l}\text { macht } \\
\begin{array}{l}\text { God is goed en } \\
\text { rechtvaardig }\end{array}\end{array}$ & 46 & 81 & 87 & 71 & 87 & 4 & 4 & 11 \\
\hline
\end{tabular}


Dat er iets hogers bestaat wordt door de meerderheid van de gereformeerde, hervormde, christelijke en humanistische leerlingen erkend, evenals dat er een hogere macht bestaat en in nog grotere mate dat God goed is en rechtvaardig. Vooral die laatste stelling vindt geen bijval van atheïstische en humanistische leerlingen. De katholieke leerlingen zijn voor een derde tot bijna de helft instemmend over deze stellingen maar duidelijk minder dan de vier andere religieuze groepen jongeren.

De 'min drie' van stellingen, dus die het meest is gescoord als 'mee oneens' of 'helemaal mee oneens', is:

God roept mij

Ik beschouw God als een man met een baard die op een wolk zit

God is gewoon een ander woord voor natuur
$66,7 \%$

$65,3 \%$

$65 \%$

$66 \%$

$65 \%$

$64 \%$

'God als man met baard op een wolk' werd toen vierde met 64 procent en 'God als ander woord voor natuur' vond toen nog iets meer bijval dan in 2017.

De verdeling over denominaties bij deze scores op deze stellingen is als volgt (in percentages die scoorden 'mee oneens' of 'helemaal mee oneens').

Tabel 9 Drie meest vaak als onbelangrijk gescoorde godsbeelden, uitgesplitst naar religieuze zelfbeschrijving

\begin{tabular}{|c|c|c|c|c|c|c|c|c|}
\hline & $\begin{array}{l}\text { RK } \\
(\mathrm{N}=140)\end{array}$ & $\begin{array}{l}\text { Her- } \\
\text { vormd } \\
(\mathrm{N}=68)\end{array}$ & $\begin{array}{l}\text { Gerefor- } \\
\text { meerd } \\
(\mathrm{N}=107)\end{array}$ & $\begin{array}{l}\text { Christen } \\
(\mathrm{N}=359)\end{array}$ & $\begin{array}{l}\text { Moslim } \\
(\mathrm{N}=38)\end{array}$ & $\begin{array}{l}\text { Atheïst } \\
(\mathrm{N}=249)\end{array}$ & $\begin{array}{l}\text { Huma- } \\
\text { nist } \\
(\mathrm{N}=27)\end{array}$ & $\begin{array}{l}\text { Geen } \\
(\mathrm{N}=851)\end{array}$ \\
\hline God roept mij & 71 & 21 & 16 & 31 & 29 & 95 & 70 & 84 \\
\hline $\begin{array}{l}\text { Ik beschouw God } \\
\text { als een man met } \\
\text { een baard die op } \\
\text { een wolk zit }\end{array}$ & 66 & 75 & 66 & 66 & 87 & 68 & 63 & 62 \\
\hline $\begin{array}{l}\text { God is gewoon een } \\
\text { ander woord voor } \\
\text { natuur }\end{array}$ & 59 & 69 & 78 & 71 & 81 & 65 & 44 & 63 \\
\hline
\end{tabular}


Dat God een ander woord voor natuur zou zijn wordt door humanisten het minst ontkend maar ook van hen vindt bijna de helft dat niet. Het kinderlijke beeld dat God een man met een baard op een wolk zit, wordt door alle categorieën verworpen. De grote meerderheid van zowel de katholieke, als atheïstische, humanistische leerlingen en ook van de leerlingen die geen lid zijn van een religie of godsdienst zijn het oneens met dit godsbeeld. De gedachte van een God die je roept, is echter door gereformeerde leerlingen beduidend minder als oneens gescoord, net als door een vijfde van de hervormden en bijna een derde van de christelijke en moslimleerlingen.

\subsection{Typen jongeren}

De vragen die tot nu toe zijn besproken hebben vooral betrekking op het betrokken zijn bij een religieus instituut en het actief bezig zijn met religie of levensbeschouwing. Op grond van soortgelijk materiaal heeft Van DijkGroeneboer (2010) vier typen jongeren onderscheiden. Die typologie deelt jongeren in naar deze twee dimensies: hun betrokkenheid bij een religieus instituut (wel/niet) en of ze actief bezig zijn met religie of levensbeschouwing in hun leven (wel/niet). Zo ontstaan vier typen jongeren. Fortissimo's zijn verbonden aan een religieus instituut en actief bezig met religie. Spirituoso's zijn actief bezig met religie of levensbeschouwing maar voelen zich niet aan een religieus instituut verbonden. Legato's zijn wel verbonden aan een religieus instituut maar niet actief met religie of levensbeschouwing bezig en Tranquillo's zijn niet actief met religie of levensbeschouwing bezig en voelen zich ook niet verbonden aan een religieus instituut. In de vragenlijst in 2017 hebben we voor het eerst een vraag opgenomen om de leerlingen ook zelf hierin een keuze te laten maken. Dus in hoeverre zijn ze volgens zichzelf actief met een religie of levensbeschouwing bezig, bijvoorbeeld in de keuzes die ze maken in hun leven, en in hoeverre voelen ze zich verbonden aan een religieus instituut of juist helemaal niet. Ook is de optie 'verbonden aan meerdere instituten' toegevoegd omdat dat in de praktijk meer voor begint te komen.

\section{Tabel 10 Typologie van jongeren op basis van zelfbeschrijving}

\begin{tabular}{lll}
\hline & $\begin{array}{l}\text { Actief met religie/ } \\
\text { levensbeschouwing bezig }\end{array}$ & $\begin{array}{l}\text { Niet actief met religie/ } \\
\text { levensbeschouwing bezig }\end{array}$ \\
\hline $\begin{array}{l}\text { Verbonden aan een religieus } \\
\text { instituut (of meer) }\end{array}$ & Fortissimo's: 11\% (6\%) & Legato's: 20\% \\
$\begin{array}{l}\text { Niet verbonden aan een } \\
\text { religieus instituut }\end{array}$ & Spirituoso's: 10\% & Tranquillo's: $53 \%$ \\
\hline
\end{tabular}


Meer dan de helft van de leerlingen kan tot de Tranquillo's worden gerekend; ze voelen zich niet verbonden aan een religieus instituut en zijn niet actief bezig met religie of levensbeschouwing. Een vijfde voelt zich wel verbonden aan een religieus instituut maar is niet actief bezig met religie of levensbeschouwing. Een tiende deel is wel actief bezig met religie of levensbeschouwing maar voelt zich niet verbonden aan een instituut. 17 procent is wel actief bezig met religie of levensbeschouwing en voelt zich verbonden met een (11\% van de $17 \%$ ) of meer (6\% van de $17 \%$ ) religieuze instituten.

Bij nadere analyse blijkt dat de Fortissimo's vooral hervormd (40\% van alle hervormde leerlingen) zijn, gereformeerd (44\%), christen (25\%) of moslim (51\%). Van alle katholieke leerlingen zegt slechts 6 procent zich verbonden te voelen aan een religieus instituut. Ook de Fortissimo's die zich aan meerdere organisaties verbonden voelen, laten een dergelijke verdeling zien ( $4 \%$ van de RK, $23 \%$ van de hervormde, $22 \%$ van de gereformeerde, $15 \%$ van de christelijke, $17 \%$ van de moslimleerlingen) en ook 4 procent van de humanistische leerlingen zegt zich actief met religie of levensbeschouwing bezig te houden en zich aan meerdere religieuze of levensbeschouwelijke instituten verbonden te voelen.

De Spirituoso's voelen zich niet verbonden aan een religieus instituut, en dit geldt voor 10 procent van de katholieke leerlingen, 6 procent van de hervormde, 9 procent van de gereformeerde leerlingen en 16 procent van de leerlingen die zich christen noemen. Wellicht vandaar ook de meer algemene keuze 'christen' in plaats van een van de andere opties. 10 procent van de moslimleerlingen kiest voor dit alternatief. Van de humanistische leerlingen is 25 procent wel actief met religie of levensbeschouwing bezig in hun leven. Ook 8 procent van de leerlingen die geen lid zijn van een religie of levensbeschouwing en 7 procent van de atheïstische leerlingen geven aan wel actief met religie of levensbeschouwing bezig te zijn in hun leven.

De uitspraak "Ik ben totaal niet met religie of levensbeschouwing bezig maar voel me wel verbonden met één religieuze instelling” is gekozen door 55 procent van de katholieke leerlingen, 29 procent van de hervormde leerlingen en 23 procent van de gereformeerde leerlingen. Ook ruim een derde (37\%) van de christelijke leerlingen koos deze uitspraak en 17 procent van de moslimleerlingen. Interessant is ook dat 10 procent van leerlingen die geen lid zijn van een religie zich wel verbonden voelt aan een religieus of levensbeschouwelijk instituut - waarvan we dus niet weten welk dat zal zijn - en dat geldt ook voor 11 procent van de humanistische leerlingen en voor 6 procent van de atheïstische leerlingen. In de typologie van Van Dijk-Groeneboer zijn dit de Legato's. 
Meer dan de helft van alle respondenten zegt dus totaal niet bezig te zijn met religie of levensbeschouwing en ook niet te horen bij een religieuze organisatie. Dit antwoord wordt gegeven door 81 procent van de leerlingen die zeggen geen lid te zijn van een religieuze instelling en door 86 procent van de atheïstische leerlingen. Ook 61 procent van de humanistische leerlingen kiest deze optie. Op de vierde plaats staan de katholieke leerlingen van wie een kwart (25\%) zegt niet met religie of levensbeschouwing bezig te zijn noch zich verbonden te voelen aan een religieus instituut. Hervormde (3\%), gereformeerde (3\%), christelijke (8\%) en moslimleerlingen (5\%) kiezen deze optie nauwelijks.

In 2012 is deze vraag niet expliciet gesteld aan de leerlingen waardoor vergelijking lastig is. Wel is toen op basis van andere vragen geschat hoeveel Fortissimo's en Tranquillo's er tussen de leerlingen zaten (Van Dijk \& Brijan 2013,17 ). Toen was 2 procent Fortissimo en 27 procent Tranquillo. Deze laatste groep lijkt verder uit te groeien, zelfs in de huidige steekproef met meer confessionele scholen, vergeleken met vijf jaar geleden. Het aantal Fortissimo's is in onderhavig onderzoek hoger dan in 2012, wat ook kan komen door de denominatie van de scholen. Bovendien is het belangrijk voorzichtig te zijn met deze conclusies omdat de vraag niet expliciet aan de orde kwam in 2012 en we dus niet weten hoe de leerlingen zichzelf zouden beschrijven.

\section{Waarden}

Iedere vijf jaar vragen we welke waarden voor leerlingen belangrijk zijn in hun leven. Het wordt steeds meer de focus omdat religie een lastiger concept aan het worden is voor veel jongeren, en we willen ontdekken wat jongeren drijft en inspireert. Om de gegevens vergelijkbaar te houden hebben we steeds dezelfde lijst met 23 waarden voorgelegd (gebaseerd op het al eerdergenoemde SOCON-onderzoek). De leerlingen konden scoren op een vijfpuntschaal, van 'helemaal onbelangrijk' tot 'helemaal belangrijk'. In tabel 11 staan de gewogen gemiddelden op deze vraag weergegeven. 
Tabel 11 Gewogen gemiddelden van waarden ( $\mathrm{N}=2233)$

\begin{tabular}{ll}
\hline Vrij en onafhankelijk zijn & 4,29 \\
Een hoge positie in de maatschappij hebben & 3,2 \\
Blij zijn met jezelf & 4,5 \\
Kinderen hebben & 3,4 \\
Rechtvaardig zijn & 4,16 \\
Veel geld verdienen & 3,5 \\
Genieten van de natuur & 3,56 \\
Mensen helpen die in moeilijkheden zitten & 3,86 \\
Grotere gelijkheid in de maatschappij bevorderen & 3,44 \\
Genieten van stille momenten & 3,38 \\
Je plicht doen & 3,71 \\
Leven voor een gezin & 3,53 \\
Altijd klaar staan voor anderen & 4,02 \\
Een goed mens zijn & 4,22 \\
Van het leven genieten & 4,49 \\
Een leven begeleid door God, Allah of een andere hogere werkelijkheid & 2,27 \\
Getrouwd zijn & 3,1 \\
Vertrouwen hebben in God, Allah of een andere hogere werkelijkheid & 2,35 \\
Open staan voor dingen buiten deze wereld & 3,24 \\
Seksualiteit beleven & 3,78 \\
Geloof hebben & 2,65 \\
Een gelukkige relatie hebben & 4,28 \\
\hline
\end{tabular}

In grafiek 4 is in een oogopslag te zien welke waarden het vaakst als belangrijk worden gescoord.

\section{Grafiek 4 Levensdoelen, gewogen gemiddelden}

Hieronder volgt een aantal algemene levensdoelen waarmee mensen proberen hun leven zin te geven. Welke levensdoelen vind jij belangrijk in jouw leven? Geef aan hoe belangrijk je elk doel vindt.

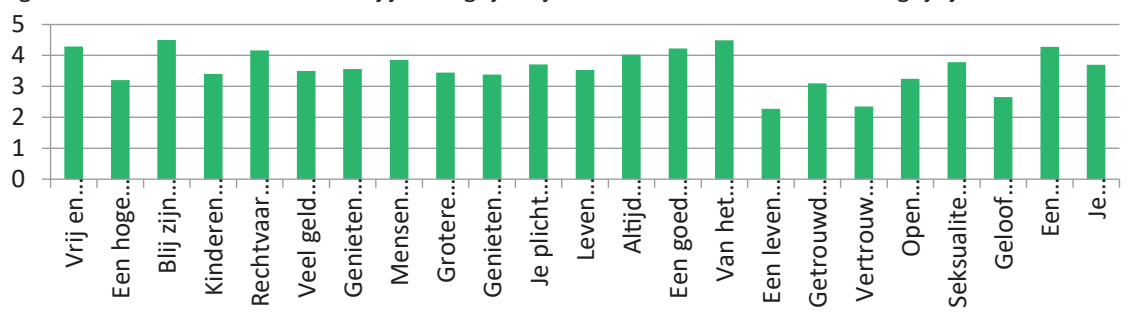


In grafiek 4 wordt zichtbaar welke drie waarden het meest als belangrijk zijn gescoord: 'vrij en onafhankelijk zijn', 'blij zijn met jezelf' en 'van het leven genieten'.

Wanneer we de religieuze achtergrond (dit is: hoe ze zichzelf t.o.v. religie en levensbeschouwingen aanduiden, hun religieuze zelfbeschrijving) van leerlingen hieraan koppelen, ontstaat een volgend overzicht.

Tabel 12 Waarden uitgesplitst naar Gewogen gemiddelden, uitgesplitst naar religieuze zelfbeschrijving ( $\mathrm{N}=2069)$

\begin{tabular}{|c|c|c|c|c|c|c|c|c|}
\hline & $\begin{array}{l}\text { RK } \\
(N=153)\end{array}$ & $\begin{array}{l}\text { Her- } \\
\text { vormd } \\
(\mathrm{N}=75)\end{array}$ & $\begin{array}{l}\text { Gerefor- } \\
\text { meerd } \\
(\mathrm{N}=119)\end{array}$ & $\begin{array}{l}\text { Christen } \\
(\mathrm{N}=417)\end{array}$ & $\begin{array}{l}\text { Moslim } \\
(\mathrm{N}=45)\end{array}$ & $\begin{array}{l}\text { Atheïst } \\
(\mathrm{N}=271)\end{array}$ & $\begin{array}{l}\text { Huma- } \\
\text { nist } \\
(\mathrm{N}=30)\end{array}$ & $\begin{array}{l}\text { Geen } \\
(\mathrm{N}=959)\end{array}$ \\
\hline $\begin{array}{l}\text { Vrij en } \\
\text { onafhankelijk zijn }\end{array}$ & 4.37 & 3.96 & 3.76 & 4.14 & 4.24 & 4.44 & 4.4 & 4.39 \\
\hline Blij zijn met jezelf & 4.51 & 4.53 & 4.34 & 4.49 & 4.62 & 4.51 & 4.67 & 4.51 \\
\hline $\begin{array}{l}\text { Van het leven } \\
\text { genieten }\end{array}$ & 4.57 & 4.29 & 4.08 & 4.41 & 4.24 & 4.59 & 4.53 & 4.56 \\
\hline $\begin{array}{l}\text { Een leven } \\
\text { begeleid door } \\
\text { God, Allah of } \\
\text { ander hoger }\end{array}$ & 2.28 & 3.88 & 3.97 & 3.41 & 4.42 & 1.35 & 1.5 & 1.63 \\
\hline $\begin{array}{l}\text { Vertrouwen } \\
\text { hebben in God, } \\
\text { Allah of ander } \\
\text { hoger }\end{array}$ & 2.43 & 3.96 & 4.1 & 3.57 & 4.47 & 1.37 & 1.67 & 1.69 \\
\hline Geloof hebben & 2.91 & 3.91 & 4.07 & 3.61 & 4.36 & 1.81 & 2.2 & 2.1 \\
\hline $\begin{array}{l}\text { Een gelukkige } \\
\text { relatie hebben }\end{array}$ & 4.35 & 4.47 & 4.29 & 4.32 & 4.56 & 4.13 & 4.3 & 4.27 \\
\hline $\begin{array}{l}\text { Een hoge } \\
\text { positie in de } \\
\text { maatschappij }\end{array}$ & 3.24 & 3.24 & 2.82 & 3.05 & 3.31 & 3.42 & 3.33 & 3.21 \\
\hline $\begin{array}{l}\text { Mensen in } \\
\text { moeilijkheden } \\
\text { helpen }\end{array}$ & 3.97 & 4.01 & 4.07 & 3.97 & 4.24 & 3.81 & 3.93 & 3.76 \\
\hline $\begin{array}{l}\text { Je inzetten voor } \\
\text { een rechtvaardige } \\
\text { maatschappij }\end{array}$ & 3.78 & 3.83 & 3.8 & 3.77 & 3.96 & 3.62 & 3.9 & 3.63 \\
\hline
\end{tabular}

De drie waarden die door alle leerlingen het meest als belangrijk of heel belangrijk zijn gescoord staan in de bovenste drie rijen van tabel 12 verdeeld naar religieuze zelfbeschrijving. Hieruit blijkt dat ook per religieuze zelfbeschrijving 
deze waarden hoog scoren, met opvallend verschil bij de variabele 'vrij en onafhankelijk zijn'. Hier scoren gereformeerde en hervormde leerlingen iets lager. Vrij en onafhankelijk zijn wordt door een kleiner aantal van hen als belangrijk of zeer belangrijk gezien in vergelijking tot hun leeftijdgenoten.

Uit grafiek 4 blijkt ook dat de waarden die het minst als belangrijk, of het meest als onbelangrijk, worden gescoord juist geloof-gerelateerd zijn. In tabel 12 zien we dat vooral veel moslimleerlingen deze waarden belangrijk vinden, en ook hervormde en gereformeerde leerlingen scoren deze waarden vaker als belangrijk of heel belangrijk. Deze twee reeksen variabelen kunnen we naast elkaar leggen. Voor moslimleerlingen is vrij en onafhankelijk zijn zowel als geloof hebben en een leven begeleid door Allah belangrijk. Voor hervormde en gereformeerde leerlingen is vrij en onafhankelijk zijn minder van belang dan geloof hebben of een leven begeleid door God.

Mensen helpen die in moeilijkheden zitten is ongeacht de denominatie of levensbeschouwing voor leerlingen belangrijk, en in iets mindere mate ook je inzetten voor een rechtvaardige maatschappij. Een hoge positie in de maatschappij hebben wordt niet vaak als belangrijk gezien. Het hebben van een gelukkige relatie is voor leerlingen van alle denominaties en levensbeschouwingen van belang.

Deze lijst met variabelen wordt al sinds 1997 aan scholieren voorgelegd, al is 'blij zijn met jezelf' in 2012 toegevoegd. Een overzicht van de waarden door de tijd kan interessant zijn voor het ontdekken van trends, al is voorzichtigheid geboden. In 2017 doen, zoals gezegd, meer protestantse scholen mee waardoor de populatie wat onvergelijkbaar kan zijn. Daarom staan in tabel 13 zowel de percentages van alle respondenten als die van de verschillende schoolsoorten, om te kijken of die factor van invloed is.

Tabel 13 Waarden in percentages, vergelijking over de tijd en in 2017 uitgesplitst naar school identiteit

\begin{tabular}{lccccccccc}
\hline & 1997 & 2002 & 2007 & 2012 & $\begin{array}{l}2017: \\
\text { Allen }\end{array}$ & $\begin{array}{l}\text { 2017: } \\
\text { RK }\end{array}$ & $\begin{array}{l}\text { 2017: } \\
\text { PC }\end{array}$ & $\begin{array}{l}\text { 2017: } \\
\text { Geref. }\end{array}$ & $\begin{array}{l}\text { 2017: } \\
\text { Reform. }\end{array}$ \\
\hline $\begin{array}{l}\text { Vrij en } \\
\text { onafhankelijk zijn }\end{array}$ & 97 & 97 & 95 & 91 & 89 & 93 & 92 & 76 & 58 \\
$\begin{array}{l}\text { Van het leven } \\
\text { genieten }\end{array}$ & 98 & 98 & 85 & 93 & 93 & 94 & 95 & 81 & 84 \\
$\begin{array}{l}\text { Een goed mens } \\
\text { zijn }\end{array}$ & 86 & 86 & 89 & 83 & 87 & 87 & 87 & 90 & 92 \\
Blij zijn met jezelf & -- & -- & -- & 93 & 94 & 94 & 95 & 91 & 96 \\
\hline
\end{tabular}


Het percentage leerlingen dat vrij en onafhankelijk zijn belangrijk vindt, is in 2017 voor de totale groep lager dan in 2012, maar de vergelijkbaarheid is lastig vanwege de andere samenstelling van deelnemende scholen. In de reeks is te zien dat met name leerlingen van reformatorische scholen en in mindere mate van gereformeerde scholen zorgen voor het lagere totaalpercentage. Op katholieke en protestants-christelijke scholen zijn de percentages hoger en dan zelfs hoger dan in 2012. 'Van het leven genieten' is wederom in 2017 belangrijk voor veel leerlingen, waarbij de lagere aantallen in 2007 opvallen. Voor leerlingen op gereformeerde en reformatorische scholen blijkt dit een minder belangrijke waarde te zijn. 'Een goed mens zijn' scoort in 2017 hoger dan in 2012, en dit komt mede door de reformatorische en gereformeerde scholen waar dit aantal hoog ligt, maar ook op de andere scholen is het gemiddelde percentage leerlingen dat het belangrijk vindt een goed mens te zijn hoog, hoger dan in 2012.

\section{Inspiratie}

We hebben ook gevraagd naar door wie jongeren geïnspireerd worden. Er werden acht mogelijkheden genoemd waarop zij konden aangeven of ze door hen werden geïnspireerd en daarna was er ruimte specifieke namen te noemen. De opties waren: 'iemand in de eigen omgeving', 'filmsterren, popsterren en muzikanten', 'sportmannen en -vrouwen', 'wereldleiders en politici', 'mensen met een ideaal', 'kunstenaars en schrijvers', 'stichters van een godsdienst of religie' of 'iemand anders'. Het is opvallend dat $60 \%$ iemand in zijn/haar omgeving noemt. Hier worden soms namen genoemd van wie niet te achterhalen is wat de relatie van de genoemde persoon met de respondent is. Toch noemde bijna de helft $(\mathrm{n}=639)$ zijn/haar ouders en 248 hiervan noemde andere familieleden. Vrienden worden door 147 leerlingen genoemd. Op de tweede plaats van mensen die inspireren komen filmsterren, popsterren en muzikanten, genoemd door $55 \%$. Heel veel namen worden hier genoemd, allemaal door een klein aantal respondenten. De namen die het meest genoemd werden, zijn Ed Sheeran, Beyoncé, Shawn Mendes, Emma Watson, Martin Garrix en Michael Jackson. Op de derde plek komen sportmannen en -vrouwen, genoemd door bijna de helft (47\%). Hier sprongen voetballers Lionel Messi en Christiano Ronaldo eruit. De vierde groep zijn wereldleiders en politici, genoemd door $42 \%$. Obama sprong hier het meest uit, met 283 respondenten. Trump en Wilders kregen samen 70 respondenten. Ook premier Mark Rutte (36) en Nelson Mandela (42) zijn genoemd. Kort hierop volgt de 
vijfde groep van mensen met een ideaal met $41 \%$. Hier werd Nelson Mandela 92 keer genoemd, en kinderrechtenactiviste Malala 43 keer. Op de zesde plek staan kunstenaars en schrijvers (39\%). Vincent van Gogh wordt door 42 leerlingen genoemd, meer dan Rembrandt die door 18 leerlingen wordt genoemd. Harry-Potter-schrijfster J.K. Rowling wordt 32 keer genoemd. Stichters van een godsdienst of religie komen op de zevende plek (36\%). Jezus wordt hier 148 keer genoemd, Mohammed 28 keer en God 21 keer. Op de laatste plaats wordt 'iemand anders' genoemd. Hier zijn wederom voorbeelden zoals familie en ouders (85) en vrienden (46) door leerlingen genoemd. Ook hier wordt Nelson Mandela door 4 respondenten genoemd. Dat betekent dat hij in totaal 128 keer genoemd is. Er waren 753 leerlingen die 'niemand' hebben ingevuld bij de laatste optie.

In 2012 was de volgorde van inspiratiefiguren vergelijkbaar: op de eerste plaats iemand uit de eigen omgeving (58\%), gevolgd door filmster/popster/muzikant (55\%), sportman/vrouw (48\%), wereldleiders/politici (40\%). De vijfde plek was toen voor kunstenaars/schrijvers (39\%) en de zesde voor mensen met een ideaal (38\%).

\section{Eigen woorden voor levensbeschouwing}

Er is aan de leerlingen aangegeven dat woorden zoals geloof en levensbeschouwing vaak door elkaar lopen. Vervolgens is gevraagd welke woorden zij zelf het liefst gebruiken voor de thema's in deze enquête zoals geloof, religie of levensbeschouwing. Dat geeft het volgende resultaat.

\section{Grafiek 5 Woorden die leerlingen zelf gebruiken}
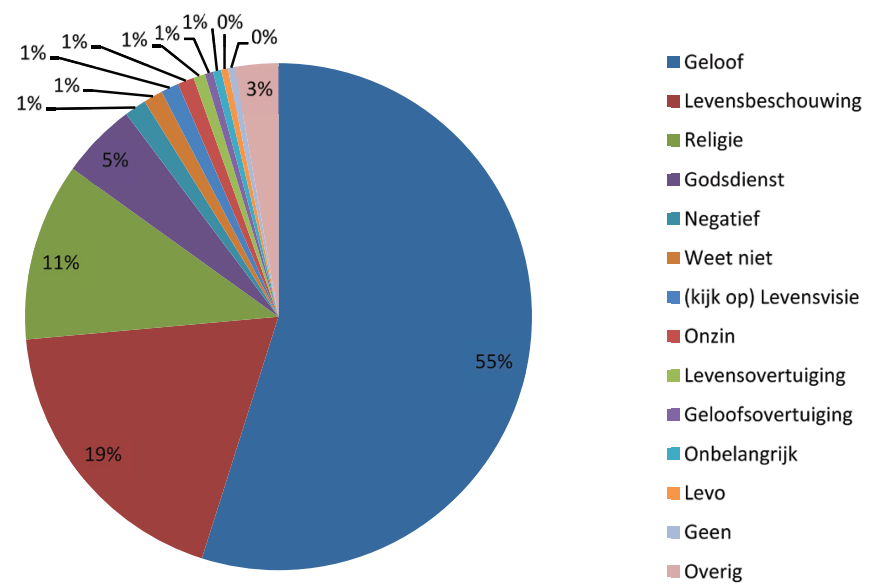
Ruim de helft van de jongeren zou het woord geloof gebruiken (55\%). Een vijfde (19\%) zou kiezen voor het woord levensbeschouwing. 11 procent van de leerlingen koos voor het woord 'religie' en slechts 5 procent jongeren koos voor het woord godsdienst. Wat opviel was dat 32 leerlingen een negatieve waardering gaven van dit terrein, zoals geld of oorlog, nep, irrelevant en tijdverspilling. Ook gaf 1 procent van de leerlingen 'onzin' als woord dat zij het liefst gebruiken, wat ook als negatief geduid kan worden. Er zijn $6_{3}$ antwoorden gecategoriseerd als overig. Hier kwamen woorden naar voren zoals filosofie, overtuiging, identiteit, cultuur, liefde en geluk. In deze vraag komen we voor het eerst op het spoor van de taal die leerlingen zelf gebruiken voor religie of levensbeschouwing.

In 2012 is een bijna gelijke verdeling te zien: er werd door 46 procent van de leerlingen ook voor het woord 'geloof' gekozen en 22 procent voor 'levensbeschouwing'. Het woord 'religie' werd toen door acht procent gekozen en eveneens vijf procent koos toen voor het woord 'godsdienst'.

\section{Wat is nu belangrijk?}

In het onderzoek is tot slot de vraag gesteld aan de leerlingen wat ze belangrijk vinden in hun eigen leven op het gebied van religie, geloof, zingeving en levensbeschouwing. Dit was een open vraag, en hier kwamen heel veel verschillende en boeiende antwoorden uit. Ruim 2000 antwoorden zijn er gegeven. Ruim een vijfde van de antwoorden waren zo uiteenlopend dat hierin minder gemeenschappelijke verbanden te leggen zijn. Over de rest is wel wat te zeggen omdat daar gemeenschappelijke thema's in gevonden zijn door hun antwoorden te labelen.

433 leerlingen (21 procent) zeiden niks belangrijk te vinden. Wat soms uit de antwoorden bleek, was dat er een nauwe opvatting van religie/geloof/zingeving en levensbeschouwing was. In veel antwoorden hierop werd specifiek gerefereerd aan geloof en minder aan bijvoorbeeld zingeving. Zo werd gezegd niet te geloven, bijvoorbeeld door te zeggen: 'Niks, ik heb geen geloof of niets anders.' Toch waren er 125 leerlingen die wel een bredere opvatting noemden en het hadden over het doel of de zin van het leven. Hiervan waren 54 leerlingen niet-religieus. Ook leven na de dood werd genoemd.

Het meest opvallende was dat er een grote groep (18 procent) is die primair noemde dat ze vrijheid en respect voor elkaar belangrijk vinden. Het gaat hierbij om 379 reacties. Hiervan was het grootste gedeelte (254) niet-religieus. Zij gaven antwoorden zoals: 'Ik vind het belangrijk dat iedereen vrij is om 
te geloven wat je zelf wilt, maar dat je je geloof niet bij anderen moet opdringen. Het is ieders eigen keuze.' Een ander voorbeeld was: 'Ik vind het belangrijk dat mensen kunnen geloven wat ze willen, en dat iedereen geaccepteerd moet worden voor wat ze (willen) geloven.' Er waren ook religieuze leerlingen die vrijheid en respect noemden in wat ze belangrijk vinden. Hier werd bijvoorbeeld gezegd: 'Vrijheid dat mensen die willen geloven daar de ruimte en de vrijheid voor hebben'.

Een andere groep wordt gevormd door leerlingen die deze vraag met 'individueel' beantwoordt en gaat voor geluk en succes. Het gaat om 199 leerlingen. De groep van 63 scholieren die aangeven in zichzelf te geloven is hier ook bij gerekend. Antwoorden zijn 'Gelukkig zijn met wie je bent', 'Alles uit het leven halen en 'plezier'.

Er zijn 348 jongeren die een religieus antwoord gaven. De genoemde woorden waren bijvoorbeeld kerk, goed gevoel bij het geloof, bidden en bijbellezen en geloven in God en geloven met anderen. De verhalen waren hier zeer uiteenlopend, van erg gelovig, tot meer gericht op het sociale in de kerk. Zo was er iemand die zei: 'Jezus speelt een belangrijke rol in mijn leven en ik probeer zoveel mogelijk te leven zoals in de Bijbel beschreven staat. Ik probeer op alle vlakken van mijn leven God erbij te betrekken.' Iemand anders was wat meer bezig met het sociale aspect van de kerk, en zei: 'Dat je er met mensen over kan praten'. Ook steun en veiligheid werd belangrijk gevonden, zoals het geloven in leven na de dood.

Er zijn 158 leerlingen die het antwoord koppelen aan hun naasten, familie of vrienden (8 procent). Zo werd als belangrijk genoemd: 'De mensen die ik lief heb'. Een ander antwoord is: 'Ik vind het belangrijk om goed te zijn voor anderen, maar ik geloof niet in iets bovennatuurlijks'.

In de categorie 'overig' (21 procent) zit onder anderen een groep die het heel belangrijk vindt om iets 'goeds te doen'. Het gaat hier om 97 mensen. Hierbij werd genoemd om goed voor de aarde te zorgen, normen en waarden en goed je best doen. Tevens een groep die vooral 'kennis' heel belangrijk vindt, bijvoorbeeld de wetenschap zelf, of meer over de wereld te weten komen. Hierbij gaat het om 72 leerlingen. 


\section{Grafiek 6 Wat leerlingen belangrijk vinden op het gebied van religie en levensbeschouwing}

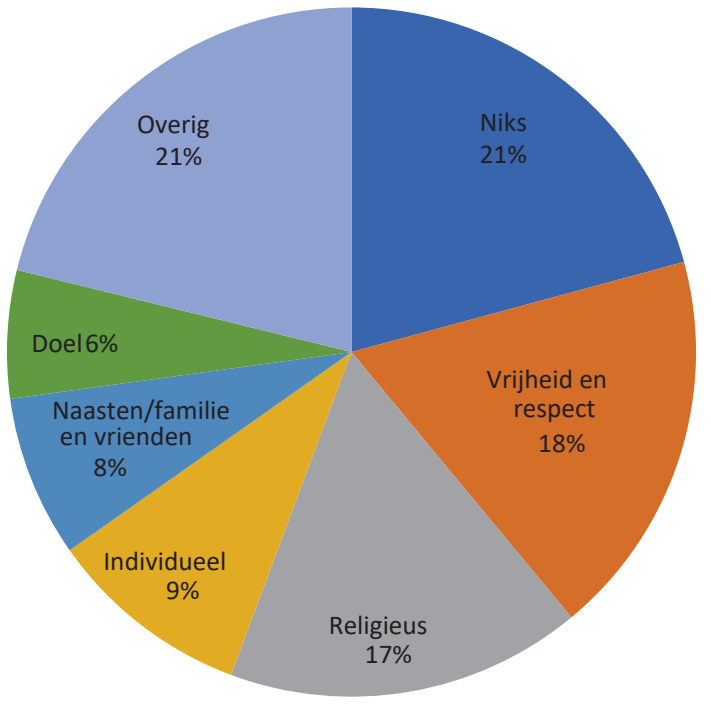

Een aantal citaten van jongeren die aangeven zichzelf niet religieus te noemen, geen lid van een religie of levensbeschouwing te zijn en niet betrokken zijn bij een religie noch er actief mee bezig, zijn de moeite waard om hier specifiek te benoemen.

- Ik ben niet zo bezig met geloof of zingeving, ik doe gewoon wat goed voelt.

- Gewoon iedereen behandelen zoals jezelf behandeld wil worden.

- Dat je zelf gelukkig bent en andere mensen helpt maakt niet uit wat ze geloven, dat is persoonlijk.

- Andere meningen/religies/levensovertuigingen accepteren en erover praten en discussiëren.

- Ik vind het belangrijk dat mensen met een geloof, andere geloven ook accepteren en niet doen alsof alleen hun religie telt.

- Ik vind het belangrijk dat iedereen zich veilig en goed voelt. Dat iedereen gelijk is en dat er vrede is in plaats van al die stomme oorlogen.

- Dat iedereen het accepteert en dat je niet wordt gediscrimineerd op basis hiervan.

- Ik vind het wel belangrijk dat mensen goed met elkaar omgaan en een goed besef hebben van de wereld, maar voor mij hoort daar niet een bepaald geloof bij.

- Dat we allemaal goed met elkaar om kunnen gaan, zonder gepest of grotere problemen zoals oorlog, dat dat niet meer nodig is. 
Deze uitspraken demonstreren dat er ook bij deze groep jongeren zinvolle gesprekken gevoerd kunnen worden over de kernwaarden in het leven en hoe mensen kunnen bijdragen aan de samenleving vanuit die kernwaarden. Door de antwoorden op de open vraag komen we op het spoor van een nieuwe taal om met jongeren in gesprek te gaan over hun waarden en inspiratiebronnen.

\section{Conclusie: zingeving bij jongeren}

De resultaten van dit grote kwantitatieve onderzoek brengen aan het licht dat religiositeit steeds meer in verandering is bij jongeren. Zeker wanneer we beginnen bij de traditionele opvatting van de daarmee verband houdende concepten zoals kerkgang, bidden en godsbeelden. Daarin bevestigt dit onderzoek de resultaten uit algemene kwantitatieve onderzoeken die de laatste jaren in Nederland verschenen (Bernts \& Berghuis 2016; De Hart \& Van Houwelingen 2018). Kerkgang neemt af, jongeren noemen zich vaker niet behorend tot een religie of levensbeschouwing en meer jongeren vinden dat als je gelooft je geen religie of kerk nodig hebt.

Tegelijk kunnen we met dit onderzoek verder kijken naar de waarden en zingeving van jongeren. Door hen te vragen naar hun eigen woorden voor wat en wie hen inspireert komen we bij hun eigen taal voor wat zij van waarde vinden. Wanneer we namelijk niet beginnen bij de genoemde verouderde concepten zoals religie, kerk, geloof, maar inzoomen op hun waarden, hun inspiratiefiguren en de woorden die zij zelf geven aan wat hen bezighoudt op dit gebied, ontstaat er een nieuw perspectief op wat religiositeit voor deze leeftijdsgroep kan inhouden. In het persoonsvormende vak levensbeschouwing op school, of hoe zich dit in de nabije toekomst ook verder ontwikkelt, kan met deze gegevens worden aangesloten bij de taal en waarden van jonge mensen. Dan kan in lessen verbinding worden gemaakt met hun waarden via hun eigen taal en van daaruit kan er gezamenlijk verder worden geleerd en geëxploreerd. Ook religieuze instellingen en organisaties die op zoek zijn naar aansluiting met jongeren kunnen beginnen bij hun taal en inspiratie. Jonge mensen vinden het belangrijk een goed mens te zijn en ook vrij en onafhankelijk te zijn. Maar een ander hebben waarmee je dit deelt, is niet voor iedereen vanzelfsprekend, zo blijkt. Spreken over wie je inspireert en delen wat voor jou van waarde is, helpt jongeren zichzelf meer bewust te worden van die waarden. Vanuit die waarden kunnen keuzes gemaakt worden voor het goede leven. Daarin kan onderwijs een rol spelen, als er echt ruimte is voor eigen woorden en vrijheid, zonder echter de ander daarbij uit het oog te verliezen. 


\section{Noten}

1 Zie: Dijk-Groeneboer M. van \& J. Maas (2001), Op Zoektocht: Levenslang!, Utrecht: Katholieke Theologische Universiteit Utrecht, Dijk-Groeneboer M. van \& J. Maas (2005), Geloof? Ff checke!, Utrecht: Katholieke Theologische Universiteit Utrecht, Dijk-Groeneboer M. van, J. Maas \& H. van den Bosch (2008), Godsdienst? Lekker belangrijk!, Tilburg: Faculteit Katholieke Theologie Tilburg, Dijk-Groeneboer M. van \& B. Brijan (2013), Kerk uit zicht? Jongeren inspireren!, Faculteit Katholieke Theologie Tilburg.

2 SOCON Datasets 1979-2005, Dans Den Haag 2005.

3 Bijvoorbeeld: Halman c.s. Changing Values and Beliefs in 85 Countries, Brill Leiden/ Boston 2008.

4 Zie bijvoorbeeld: www.curriculum.nu, VOS/ABB: Onderwijs om te koesteren 2017, Onderwijs 2032 .

\section{Literatuur}

Bernts, A.P.J. \& J. Berghuijs (2016),

God in Nederland, Utrecht: Ten Have.

Dijk-Groeneboer M. van \& J. Maas (2001),

Op Zoektocht: Levenslang!, Utrecht: Katholieke Theologische Universiteit Utrecht.

Dijk-Groeneboer M. van \& J. Maas (2005),

Geloof? Ff checke!, Utrecht: Katholieke Theologische Universiteit Utrecht.

Dijk-Groeneboer M. van, J. Maas \& H. van den Bosch (2008),

Godsdienst? Lekker belangrijk!, Tilburg: Faculteit Katholieke Theologie Tilburg.

Dijk-Groeneboer, M.C.H. van (2010),

Handboek Jongeren en Religie, Almere: Parthenon.

Dijk-Groeneboer M. van \& B. Brijan (2013),

Kerk uit zicht? Jongeren inspireren!, Tilburg: Faculteit Katholieke Theologie Tilburg.

Elsinga, R., P. Scheepers, K. Kraaykamp \& P. Thijs (2012),

Religion in Dutch Society 2011-2012, Amsterdam: Amsterdam University Press.

Halman, Loek et. al. (2008),

Changing Values and Beliefs in 85 Countries, Leiden/Boston: Brill.

Hart, Joep de \& Pepijn van Houwelingen (2018),

Christenen in Nederland. Kerkelijke deelname en christelijke gelovigheid, De Haag:

Sociaal en Cultureel Planbureau.

Platform Onderwijs 2032 (2016),

Ons Onderwijs 2032. Eindadvies, Den Haag: Bureau Platform Onderwijs2032.

SOCON Datasets 1979-2005, (2005), Den Haag: Dans.

VOS/ABB (2017),

Onderwijs om te koesteren

www.curriculum.nu 